\title{
EFFECT OF TRANEXAMIC ACID ON FRACTURE HEALING IN RATS
}

\section{EFEITO DO ÁCIDO TRANEXÂMICO NA CURA DE FRATURA EM RATOS}

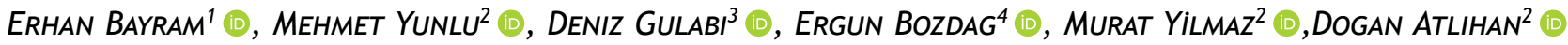 \\ 1. Istinye University Gaziosmanpasa Medicalpark Hospital, Istanbul Turkey. \\ 2. Haseki Training and Research Hospital, Department of Orthopedics and Traumatology, Istanbul, Turkey. \\ 3. Kanuni Sultan Süleyman Training and Research Hospital, Department of Orthopedics and Traumatology, Istanbul Turkey. \\ 4. Istanbul Technical University, School of Mechanical Engineering, Biomechanics and Strength of Materials Laboratory, Istanbul, Turkey.
}

\section{ABSTRACT}

Introduction: In this study we investigated the effect of tranexamic acid (TXA) on fracture healing in an established animal model, when used to stop bleeding in orthopedic trauma surgery. Materials and Methods: This study was a randomized, controlled, laboratory study. Eighteen Sprague-Dawley rats were randomly assigned to three groups, either receiving TXA intravenously (Group 1), TXA topically (Group 2), or isotonic TXA intravenously and TXA topically in the same amounts for the control group (Group 3). First, a Kirschner wire was inserted retrogradely into the femoral intramedullary canal. Then the femurs were fractured at the midshaft region with blunt guillotine. After 4 weeks, the rats were sacrified and the femurs harvested. Cortical bone volume, callus volume, and bone mineral density were calculated using computer tomography scans. Torsion tests were performed. Groups were compared by maximum torque to failure and callus stiffness. Results: There were no statistical differences in torque to failure and stiffness between the 3 groups. There were no differences in mean total bone volume, callus volume, percent bone volume, or callus density between the groups. Conclusions: A single dose of topical or intravenous TXA has no negative effect on fracture healing when used in traumatic femur fracture surgery in an animal model. Evidence level II; Randomized controlled experimental study.

Keywords: Fracture. Orthopedic surgery. Tranexamic acid.

\section{RESUMO}

Introdução: Neste estudo, investigamos o efeito do ácido tranexâmico (TXA) sobre a consolidação de fraturas em um modelo animal estabelecido, quando é usado para estancar o sangramento em cirurgias de trauma ortopédico. Materiais e Métodos: Trata-se de estudo de laboratório randomizado e controlado. Dezoito ratos Sprague-Dawley foram atribuídos randomicamente em três grupos, que receberam TXA por via intravenosa (Grupo 1), TXA tópico (Grupo 2) ou isotônico por via intravenosa e tópico na mesma quantidade como grupo controle (Grupo 3). Primeiro, foi inserido um fio de Kirschner por via retrógrada no canal intramedular femoral. Em seguida, o fêmur dos animais foi fraturado na região média do corpo do fêmur com guilhotina romba. Depois de quatro semanas, os ratos foram sacrificados e os fêmures foram retirados. 0 volume do osso cortical, o volume do calo e a densidade mineral óssea foram calculados por meio de tomografia computadorizada e foram realizados testes de torção. Os grupos foram comparados de acordo com o torque máximo até a falha e a rigidez do calo. Resultados: Não houve diferença estatística no torque até a falha e rigidez entre os três grupos nem diferenças entre os grupos quanto ao volume médio total do osso, volume e densidade do calo e percentual de volume ósseo. Conclusões: Uma dose única de TXA tópico ou intravenoso não tem efeito negativo sobre a consolidação da fratura quando usada em cirurgia de fratura traumática de fêmur em modelo animal. Nível de evidência II; Estudo experimental controlado randomizado.

Descritores: Fratura. Cirurgia ortopédica. Ácido tranexâmico.

Citation: Bayram E, Yunlu M, Gulabi D, Bozdag E, Yilmaz M ,Atlihan D. Effect of tranexamic acid on fracture healing in rats. Acta Ortop Bras. [online]. 2022;30(1): Page 1 of 4. Available from URL: http://www.scielo.br/aob.

\section{INTRODUCTION}

Uncontrolled bleeding and subsequent high blood loss is still one of the main causes for mortality and morbidity after severe multiple trauma. Life threatening blood loss has also been managed with relatively liberal use of allogeneic blood transfusions. Blood transfusions are associated with an increased risk of bacterial and viral infection and increased length of hospital stay ${ }^{1,2}$. Previous studies have also showed allogeneic blood transfusion to be associated with a significantly increased risk of postoperative infection? ${ }^{2}$.
Tranexamic acid (TXA), a synthetic derivative of the amino acid lysine, is an antifibrinolytic agent that acts by binding to plasminogen and blocking the interaction of plasminogen with fibrin, thereby preventing dissolution of the fibrin $\mathrm{clot}^{3}$. TXA has demonstrated efficacy in reducing transfusion rates without increasing complications in patients undergoing elective orthopedic surgery, including arthroplasty and spine surgery ${ }^{4,5}$. TXA also inhibits plasmin, which is known to induce proinflammatory effects by activation of monocytes, neutrophils, platelets, and endothelial cells; and by

\section{All authors declare no potential conflict of interest related to this article.}


inducing lipid mediators, cytokines, and proinflammatory genes ${ }^{6}$. TXA acts like anti-inflammatory drugs, which have been associated with nonunion of fractures ${ }^{7}$.

The aim of the current study was to investigate the effect of TXA on fracture healing in an established animal model, when used to stop bleeding in orthopedic trauma surgery. It was hypothesized that TXA would not reduce healing potential. This would provide valuable information regarding the potential clinical utility of TXA during orthopedic fracture fixation surgery.

\section{MATERIAL AND METHOD}

This study was approved by the Istanbul University Ethic Committee for Animal Experiments (2018/06) and all the procedures were in accordance with the 1995 Helsinki Declaration and the Ethics in Experimentation Animals. A total of 18 four-month-old male Sprague - Dawley rats, each weighting $400 \mathrm{~g}$ (380-420), were obtained from the central animal unit of Istanbul University and randomly assigned to three groups, either receiving TXA (30 mg/kg) intravenously (Group 1); TXA $30 \mathrm{mg} / \mathrm{kg}$ topical (Group 2); or a matched volume of $0.9 \%$ $\mathrm{NaCl}$ solution intravenously (Group 3). TXA dosage was calculated as Roy et al. ${ }^{8}$ described in their animal study. The animals were kept under standardized conditions regarding temperature $\left(22^{\circ} \mathrm{C} \pm 1^{\circ} \mathrm{C}\right)$, humidity (55\% - 5\%), and 12-h/12-h light-dark cycles, and were fed ad libitum (Ssniff-Spezialdiäten, Soest, Germany) with free access to water and were not fasted before the experiments. At the postoperative period we used systemic analgesic (buprenorphine $0.01 \mathrm{mg} / \mathrm{kg}$ ) for pain control. Kokubu et al. showed that they achieved hard callus and bridging callus formation at 4 weeks. So, we choosed timeframe as 4 weeks ${ }^{9}$. At the end of week 4 , all rats sacrified with injection of sodium pentobarbital $(250 \mathrm{mg} / \mathrm{kg})$. All femurs disarticulated and all soft tissue removed. After BT anaylses all bones wrepped in saline soaked gauze and frozen at $-40^{\circ} \mathrm{C}$.

\section{Femur Fracture Model}

The skin was cleaned with alternating chlorhexidine and $70 \%$ ethanol scrubs. After a preoperative subcutaneous dose of buprenorphine hydrochloride analgesia (0.03-0.05 mg/ $\mathrm{kg}$ ), surgical anesthesia was achieved with a mixture of ketamine $(80-120 \mathrm{mg} / \mathrm{kg})$ and xylazine $(12-16 \mathrm{mg} / \mathrm{kg})$ introduced intraperitoneally. We introduced $0.12 \mathrm{ml}$ TXA (30 mg/kg) for group 1 and $0.12 \mathrm{ml}$ saline for group 2 and 3 parenteraly. ${ }^{8}$ With a sterile technique, a $20-\mathrm{mm}$ longitudinal incision was made over the medial knee joint. The medial structures stabilizing the patella were divided and the patella manually dislocated laterally. A 1.2-mm-diameter Kirschner wire (TST, Istanbul, Turkey) was inserted retrograde into the femoral intramedullary canal beginning between the femoral condyles. The pin was cut as close as possible to the knee articular cartilage so that the tip was flush with the cartilage. The patella was relocated and stabilized with absorbable sutures, and the skin incision closed using suture clips. The femur was fractured at the midshaft using a three-point bending force generated by a blunt guillotine technique, as previously described ${ }^{10}$. After this a $10-\mathrm{mm}$ lateral incision was made at midshaft region of femur. Through an intramusculer approach fracture site visualised. $0.12 \mathrm{ml}$ txa injected to fracture site for group 2 and the same amount of saline injected to fracture site for goup 1 and 3 and the skin incision closed using suture clips.

\section{Biomechanical Analyses}

The bones were thawed at room temperature in a saline bath 24 hours before mechanical testing. Torsion tests were performed until failure with a constant angular speed of $3 \%$ second (MTS, İstanbul Technical University). The torque - angular displacement curve was obtained and used to determine callus stiffness. Maximum torque to failure was obtained from the same data.

\section{Radiologic Analyses}

Kirschner wires were removed before CT analyses. Scans were obtained for a $10-\mathrm{mm}$ midshaft region of each bone, with the fracture line in the middle. Ten axial slices each $1 \mathrm{~mm}$ thickness were obtained from each scan. In all sections the image of callus and cortical bone segmented manually after adjustment window. A three-dimensional reconstruction was made (Figure 1). Cortical bone volume and callus volume and bone mineral density were calculated by computer (Philips Extended Brilliance Workspace V4.5.6.52040). Total bone volume and callus volume was calculated as $\mathrm{mm}^{2}$, and Callus Bone Density was calculated as $\mathrm{mg} / \mathrm{cm}^{2}$.

\section{Sample Size}

Sample size was calculated with $G *$ Power Version 3.1.6 program (Faul F, Erdfelder E, Buchner A, Lang AG. (2009). Statistical power analyses using $G *$ Power 3.1: Tests for correlation and regression analyses. Behavior Research Methods, 41, 1149-1160.). It was determined that biomechanical testing for 6 rats per group was adequate to detect a medium effect size (effect size $=1$ ) with a statistical power of 0.95 and $p<0.05$.

\section{Statistical Analyses}

All data are reported as the mean and standard deviation. The statistical differences between groups were evaluated with a paired t-test and significance was set at $p<0.05$. Moment and stiffness differences between groups were assessed using the Kruskal-Wallis non-parametric test. Statistical analyses were performed using SPSS version 16.0 (SPSS Inc. Released 2007. SPSS for Windows, Version 16.0. Chicago, SPSS Inc.).

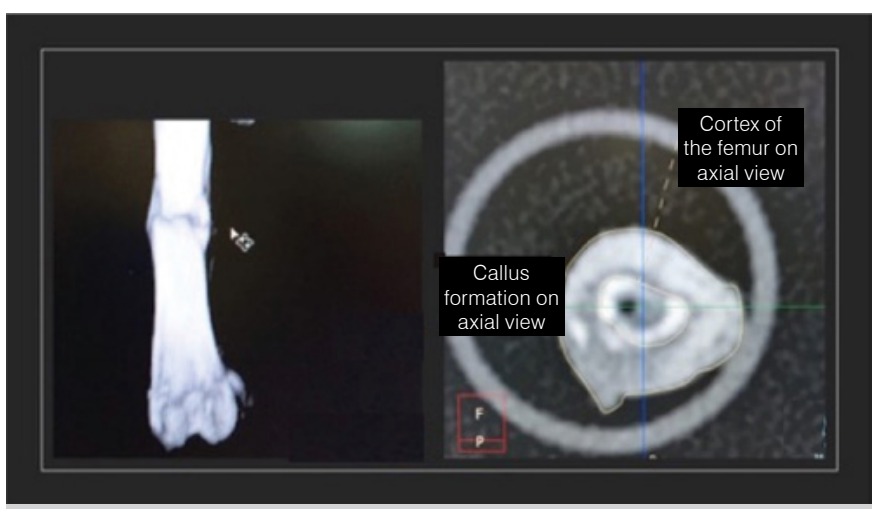

Figure 1. 3- dimensional reconstruciton of the femur and cortical bone - callus formation on axial

\section{RESULTS}

No animals were excluded because of operative or post-operative complications.

Torque to failure and stiffness were used as predictors for fracture healing. Torque to failure in groups 1,2 , and 3 were 164.95 \pm 35.05 , $132.73 \pm 48.54$, and $233.04 \pm 120.45 \mathrm{Nmm}$, respectively. The torque load before fracture was slightly higher in the control group but this difference was not significant $(p=0.12)$. There was no significant difference in stiffness between the 3 groups $(32.75 \pm 16.25$, $42.83 \pm 17.46$, and $51.28 \pm 28 \pm 43 \mathrm{Nmm} / \mathrm{deg}$ for groups 1,2 , and 3 , respectively, $p=0.491$ ) (Table 1 ).

\section{Radiologic Analyses}

We analyzed the total volume, callus volume and density of the new bone with CT scans. Total bone volume was $29.32 \pm 7.70 \mathrm{~mm}^{2}$ for group 1, $29.23 \pm 5.02$ for group 2, $24.83 \pm 9.54 \mathrm{~mm}^{2}$ for group 3, callus volume was $17.60 \pm 9.27 \mathrm{~mm}^{2}$ for group $1,19.25 \pm 4.2 \mathrm{~mm}^{2}$ 
for group 2 and $16.20 \pm 9.50 \mathrm{~mm}^{2}$ for group 3.Callus bone density was $654.71 \pm 95.36 \mathrm{mg} / \mathrm{cm}^{2}$ for group $1,603.14 \pm 62.90 \mathrm{mg} / \mathrm{cm}^{2}$ for group 2, and $583.57 \pm 85.61 \mathrm{mg} / \mathrm{cm}^{2}$ for group 3. There were no differences between the groups in mean total bone volume, callus volume, percent bone volume, or callus density. The results are shown in Table 2.

\section{Table 1. Biomechanical test results.}

\begin{tabular}{c|c|c|c|c}
\hline & Group 1 & Group 2 & Group 3 & p-value \\
\hline Torque $(\mathrm{Nmm})$ & $164.95 \pm 35.05$ & $132.73 \pm 48.54$ & $233.04 \pm 120.45$ & $\mathrm{p}=0.12$ \\
\hline Stiffness $(\mathrm{Nmm} / \mathrm{deg})$ & $32.75 \pm 16.25$ & $42.83 \pm 17.46$ & $51.28 \pm 28.43$ & $\mathrm{p}=0.491$ \\
\hline
\end{tabular}

Table 2. Radiologic analyses.

\begin{tabular}{c|c|c|c|c}
\hline & Group1 & Group 2 & Group 3 & p-value \\
\hline $\begin{array}{c}\text { Total Bone } \\
\text { Volume }(\mathrm{mm})\end{array}$ & $29.32 \pm 7.70$ & $29.23 \pm 5.02$ & $24.83 \pm 9.54$ & $\mathrm{p}=0.4$ \\
\hline CallusVolume (mm ) & $17.60 \pm 9.27$ & $19.25 \pm 4.20$ & $16.20 \pm 9.50$ & $\mathrm{p}=0.713$ \\
\hline Bone Volume (\%) & 56.30 & 65.47 & 61.21 & $\mathrm{p}=0.285$ \\
\hline $\begin{array}{c}\text { Callus Bone } \\
\text { Density (mg/cm ) }\end{array}$ & $654.71 \pm 95.36$ & $603.14 \pm 62.90$ & $583.57 \pm 85.61$ & $\mathrm{p}=0.648$ \\
\hline
\end{tabular}

\section{DISCUSSION}

This prospective, randomized study investigated the effect of TXA on fracture healing when used to stop bleeding during fracture surgery. The main findings of the present study were that biomechanical and radiological assessments confirmed that topical or systemic TXA did not have adverse effects on fracture healing in the animal model. There were many studies published in the literature on adverse or positive effect of treatment modalities on fracture healing ${ }^{11-14}$. TXA was widely used nowadays especially in arthroplasty and spinal surgery to decrease the blood loss and mortality and morbidities related to the bleeding and allogenic blood tranfusions. Because of the anti-inflammatory effects of TXA, we researched its effect on fracture healing. In a recent study Cevik et al. showed that topical application of TXA during orthopedic fracture surgery may accelerate fracture healing and systemic use may delay healing according to histological and radiological findings ${ }^{15}$. Our animal model demonstrated that a single dose application via systemic or topical will not affect statistically significant callus formation, volume, or density whereas total bone and callus volume. Although we could not confirm this findings with histopathological analysis, we believed that TXA could be used in fracture treatment after verifing our findings in prospective designed study including histopatological analysis. There is significant mortality and morbidity from traumatic fractures, which is associated with perioperative hemorrhage. The increased amount of blood loss can lead to complications including anemia. TXA is commonly used in knee and hip arthroplasty, and its positive effects in reducing blood loss, hemoglobin decreases, and allogenic blood transfusion rates have been reported in previous studies ${ }^{4,16}$. However, TXA is rarely used in traumatic fracture surgery, possibly due to the expectation of negative effects on fracture healing because of its anti-inflammatory properties ${ }^{17,18}$. The findings of the present study lend support to the safety of single-dose TXA use in traumatic fracture surgery.

There are some limitations in the present study. Firstly, this study investigates indirect diaphyseal femur fracture healing in a rat model, we need further researchs to learn the effect of TXA on human bone healing. Secondly, the fractures were stabilized with a non-locked Kirschner wire in the rat intramedullary canal, which helped to reduce but not eliminate micromotion. Thirdly, immunohistochemical and histopathological examinations were not conducted. Larger, well-designed, randomized controlled studies will help clarify any potential association between TXA and thromboembolic events, and more research is needed to determine the optimal dose and timing for TXA in orthopedic trauma patients.

\section{CONCLUSION}

The present study substantiate that a single dose of TXA has no negative effect on fracture healing when it is used in traumatic femur fracture surgery in an animal model. Further studies including histopathological assessments may demonstrate the safety of TXA in traumatic fracture surgery.

\section{ACKNOWLEDGMENTS}

I would like to thank to Prof Dr Hayati Durmaz for concepting and designing study, Assos Prof Funda Yigit for helping to design the study. And i want to thank to editors at WK Editage service (a division of Cactus Communications) for professional language editing. This study was supported by a grant from Haseki Training and Research Hospital Medical Specialist Education Board.

AUTHORS' CONTRIBUTION: BE: design and writing of the work; YM: design of the work, performing surgeries; GD: data analysis, critical review; BE: design of the work, performed biomechanic tests; YM: review of the article and intellectual concept of the article; AD: critical review and final approval of the version of the manuscript.

\section{REFERENCES}

1. Klein HG, Spahn DR, Carson JL. Red bloodcell transfusion in clinical practice. Lancet 2007;370:415-26.

2. Carson JL, Altman DG, Duff A, Noveck H, Weinstein MP, Sonnenberg FA, et al Risk of bacterial infection associated with allogeneic blood transfusion among patients undergoing hip fracture repair. Transfusion 1999;39:694-700.

3. Lin ZX, Woolf SK. Safety, efficacy, andcost-effectiveness of tranexamicacid in orthopedicsurgery. Orthopedics. 2016;39:119-30.

4. Yi Z, Bin S, Jing Y, Zongke Z, Pengde K, Fuxing P. Tranexamic acid administration in primary total hip arthroplasty: a randomized controlled trial of intravenous combined with topical versus single-dose intravenous administration. J Bone Joint Surg Am. 2016;98:983-91.

5. Li ZJ, Fu X, Xing D, Zhang HF, Zang JC, Ma XL. Is tranexamic acid effective and safe in spinal surgery? A meta-analysis of randomized controlled trials. Eur Spine J. 2013;22(9):1950-7.

6. Napolitano LM, Cohen MJ, Cotton BA, Schreiber MA, Moore EE. Tranexamicacid in trauma: how shouldweuse it?. Journal of Trauma and Acute Care Surgery. 2013;74(6) 1575-86.
7. Giannoudis PV, Hak D, Sanders D, Donohoe E, Tosounidis T, Bahney C. Inflammation, bone healing, and anti-inflammatorydrugs: an update. Journal of orthopaedic trauma. 2015;29:S6-S9.

8. Roy M, Burggraf M, Lendemans S, de Groot H, Rohrig R . Tranexamic acid prolongs survival after controlled hemorrhage in rats. Journal of Surgical Research. 2017;208:104-10.

9. Kokubu T, Hak DJ, Hazelwood SJ, Reddi AH. Development of an atrophic nonunion model and comparison to a closed healing fracture in rat femur. Journal of Orthopaedic Research. 2003;21:503-10.

10. Bonnarens F, Einhorn TA. Production of a standard closed fracture in laboratory animal bone. J Orthop Res. 1984;2:97-101.

11. Sumner DR, Turner TM, Urban RM, Virdi AS, Inou N. Additive enhancement of implant fixation following combined treatment with rhTGF-b2 and rhBMP-2 in a canine model. J Bone Joint Surg Am 2006;88:806-817.

12. Angle SR, Sena K, Sumner DR, Virkus WW, Virdi AS. Combined use of low-intensity pulsed ultrasound and rhBMP-2 to enhance bone formation in a rat model of critical size defect. J Orthop Trauma. 2014;28:605-11. 
13. Ratanavaraporn J, Furuya $\mathrm{H}, \mathrm{Kohara} \mathrm{H}$, Tabata Y. Synergistic effects of the dual release of stromal cell-derived factor-1 and bone morphogenetic protein-2 from hydrogels on bone regeneration. Biomaterials 2011;32:2797-811.

14. Inal, S., Kabay, S., Cayci, M. K., Kuru, H. I., Altikat, S., Akkas, G. et al. Comparison of the effects of dexketoprofen trometamol, meloxicam and diclofenac sodium on fibular fracture healing, kidney and liver: an experimental rat model. Injury 2014;45: 494-500.

15. Çevik HB, Eceviz E, Çilingir Kaya ÖT, Ercan F, Çeçen GS. The effect of topical and systemic tranexamic acid on fracture healing in rats. Acta Orthop Traumatol Turc 2020; 54: 207-12.
16. Lacko M, Cellar R, Schreierova D, Vasko G. Comparison of intravenous and intra-articular tranexamic acid in reducing blood loss in primary total knee replacement. Joint Diseases and Related Surgery. 2017;28:64-71.

17. Amer KM, Rehman S, Amer K, Haydel C. Efficacy and Safety of Tranexamic Acid in Orthopaedic Fracture Surgery: A Meta-Analysis and Systematic Literature Review. J Orthop Trauma. 2017;31:520-25.

18. Gausden EB, Qudsi R, Boone MD, O'Gara B, Ruzbarsky JJ, Lorich DG. Tranexamic Acid in Orthopaedic Trauma Surgery: A Meta-Analysis. J Orthop Trauma.2017;31:513-19. 